\title{
Espiritualidade humanizadora na Cristologia de Joseph Moingt
}

\author{
Humanizing Spirituality \\ in Joseph Moingt's Cristology
}

Roberto Nentwig

\section{Resumo}

Os desafios da pós modernidade são um convite para que se apresente uma espiritualidade humanizadora. Esta é construída a partir de um discurso relevante, ou seja, que tenha ressonância e significado para o tempo hodierno. Para tal intento, um caminho é fundamentar o discurso em Jesus: a chave de interpretação do ser humano como propôs o Concílio Vaticano II. Moingt apresenta este Deus revelador de sentido, um Deus humanizado e humanizador: evidencia a radicalidade da quenosis - o Deus que se humilha e se revela em sua história humana, interpretando os dados evangélicos. Esta revelação quenótica, muito distante dos antigos discursos metafísicos, oferece algumas pistas para uma espiritualidade humanizadora. Diante de outras possíveis, apresentamos algumas: superação do dualismo, otimismo diante da criação, da vida e da salvação, encontro de Deus no próximo e, por fim, uma espiritualidade de liberdade.

Palavras-chave: Ressignificação. Jesus Cristo. Humanização. Espiritualidade.

\section{Abstract}

The challenges of post-modernity is an invitation to present a humanizing spirituality. This is constructed from a relevant address, or that has resonance and means for today's time. For this purpose, one way is to base the discourse on Jesus: the interpretative key of the human being as 
proposed by The Second Vatican Council. Moingt presents this revelatory sense of God, a humanized God and humanizing: shows the radicalism quenosis - the God who humbles himself and is revealed in human history, interpreting the evangelical data. This quenotic revelation, far from the old metaphysical discourses, offers some clues to a humanizing spirituality. Before other possible, we present some: overcoming the dualism, optimism before the creation of life and salvation meet God in the next, and finally, a spirituality of freedom.

Keywords: Remean. Jesus Christ. Humanizing. Spirituality.

\section{Introdução}

Os autores que fazem um levantamento do contexto eclesial da atualidade, em geral, falam de uma crise, pois se constatam várias situações que demandam respostas: diminuição do número de fiéis, recuo do número de vocações, o que acarreta em problemas estruturais na ação evangelizadora da Igreja. Além disso enfrentamos a crise do obscurecimento de Deus na sociedade pós-moderna, uma crise de fé. Diante da crise, é preciso se despedir de um passado e se colocar a caminho. Estamos dispostos a partir, deixando as seguranças do passado? Neste caminho, a única missão da Igreja é ser sinal desta esperança e gérmen deste Reino. Kasper destaca três prioridades para a Igreja no atual contexto: a) falar de Deus de maneira nova como fundamento e alvo da realização humana: a Igreja não fala de si mesma, mas de Deus; b) deixar de lado uma imagem vaga sobre Deus e proclamar o Deus de Jesus Cristo; c) Tendo em conta que Jesus Cristo continua a viver e agir pelo Espirito Santo, é necessário uma renovação espiritual, que não significa um entusiasmo emocional momentâneo, mas deixar-se atingir por um fogo que queime profundamente o coração. ${ }^{1}$

Este artigo pretende oferecer algumas pistas para uma espiritualidade que faça sentido para o contexto de pós-modernidade. Partiremos do desafio de comunicação e de imagem de Deus, como destaca Kasper, e que desafia a Igreja a ressignificar o discurso do passado. Posteriormente, destaca-se Jesus Cristo como referência fundamental para falar do humano. Por fim,

\footnotetext{
${ }^{1}$ KASPER, Walter. Igreja Católica: essência, realidade e missão. São Leopoldo: Unisinos, 2012, pp. 411- 422.
} 
elencaremos algumas características para uma espiritualidade humanizadora a partir do caminho cristológico escolhido - Jesus e sua história. Estaremos fundamentados em Joseph Moingt, um dos autores que bem trabalha nesta linha: Jesus e sua história, o Cristo em sua quenosis, como ponto de partida para falar do humano.

\section{Ressignificar as verdades da fé e a espiritualidade do sentido}

A linguagem da Igreja está exposta ao envelhecimento. A simples reprodução das verdades do passado, a defesa do dogma não é mais admissível pelas novas gerações. A Igreja se vê desafiada a deixar a racionalidade sustentada pelo domínio da religião. Diante do medo de perder o poder e de trair sua própria tradição, a Igreja foi adversária da modernidade, condenando-a. Tal postura criou um atraso em seu diálogo com o tempo, havendo agora o desafio de se reconciliar com a mentalidade moderna, ressignificando os seus dogmas, revisitando o passado com abertura, de modo a encontrar interpretações muito diferentes das hermenêuticas antigas. $\mathrm{O}$ caminho para tal ressignificação é se aproximar da fonte da revelação, "redescobrindo a ideia de Deus que permaneceu velada no evento revelador". ${ }^{2}$

Os questionamentos e rupturas que surgiram com a modernidade não foram anti-cristãs, em sua completude. O eclipse de Deus na modernidade marcado pelo que se chama do anúncio cultural da morte de Deus, tem o seu aspecto positivo: lembra-nos de que os triunfos do passado ocultaram a liberdade do sujeito histórico, que pode decidir até mesmo em não seguir religião alguma. $\mathrm{O}$ eclipse de Deus liberta o ser humano de uma história teocrática, para que ele possa construir uma história humanizadora. Por outro lado, tal fato chama a atenção aos cristãos de que o cristianismo não pode ser conduzido de outra maneira, senão pelo anúncio da humanidade de Jesus Cristo, que se torna credível pelo trabalho de humanização do ser humano. ${ }^{3}$

A saída do mundo teocrático para a nova realidade requer a libertação do sono dogmático (Kant). Para atingir tal intento, há duas maneiras de fazer teologia: a partir dos textos da Escritura e da Tradição; a partir das testemunhas que narram as suas experiências de Deus. É preciso emergir a

\footnotetext{
${ }^{2}$ MOINGT, Joseph. Deus que vem ao homem. Da aparição ao nascimento de Deus. Volume II - Aparição. São Paulo: Edições Loyola, 2010a, p. 403.

${ }^{3}$ MOINGT, Joseph. O homem que vinha de Deus. São Paulo: Edições Loyola, 2008, pp. 516-517
} 
narrativa testemunhal para uma significância da fé depois da razão iluminista e da crise da modernidade. ${ }^{4}$

$\mathrm{Na}$ busca de um discurso significativo, é preciso também considerar o desafio da crise de sentido, resumida na alternativa proclamada pelo filósofo F. H. Jacobi "Deus ou nada". A grande saída da religião é apresentar Deus como o "sentido por excelência". Não se pode encontrar um sentido imanente, o sentido verdadeiro é um "metassentido". Um sentido absoluto e fontal (ômega do universo e da história) que abarca os sentidos relativos da vida: trabalho, família, ética... Sem Deus, os sentidos secundários perdem sua força e dão espaço para o aparecimento do niilismo. Deus como sentido da vida é fruto de uma experiência espiritual: a fé é experienciada e vivida, mas não se limita ao plano exterior. Por isso, a pessoa precisa ser "subjetivada", quando há apropriação pelo sujeito interiorizado, para que a fé preencha a vida de sentido. Uma fé meramente cultural, sem que o sujeito reative as suas fontes de fé, vai facilmente sucumbir à crise de sentido, afogando-se numa visão sem esperança e sem Deus (Ef 2,12). ${ }^{5}$

Uma espiritualidade humanizadora, portadora de sentido ao homem na crise da modernidade, terá que partir de Jesus Cristo, como apresentaremos na sequência.

\section{Jesus Cristo: ponto de partida para um espiritualidade humanizadora}

A mística cristã realiza-se no silêncio, mas jamais deve ser entendida como fuga da realidade: a mística cristã não causa a fuga do mundo, pois o Espírito de Deus habita a criação, enche tudo de vida: na história se realiza a ação de Deus. Realiza ainda a meditação de algo objetivo e concreto: a história de Jesus Cristo, o amor de Deus revelado na história. ${ }^{6}$

Nesta linha de espiritualidade encontra-se a grande mística, Teresa D'Avila, ao nos propor um Cristocentrismo, referenciado na humanidade de Jesus. Segundo a Santa, o cristianismo não está fundado em abstrações ou filosofias, mas numa pessoa histórica - Cristo Jesus: "E que erro seria apartar-

\footnotetext{
${ }^{4}$ BINGEMER, Maria Clara Lucchetti. O Mistério e o Mundo. Paixão por Deus em tempos de descrença. Rio de Janeiro: Rocco, 2013, pp.308-309.

${ }^{5}$ BOFF, Clodovis: O livro do sentido. Crise e busca do sentido hoje (parte crítico-analítica). Volume 1. São Paulo: Paulus, 2014, pp. 567-568.

${ }^{6}$ MOLTANN, J. O Espírito da Vida: uma pneumatologia integral. Petrópolis: Vozes, 2010, pp. 190-203.
} 
se propositadamente do que é nosso remédio: a sacratíssima humanidade de Nosso Senhor Jesus Cristo!" 7 Ao propor a humanidade de Jesus, portanto a sua historicidade, como conteúdo de meditação, Santa Teresa se distancia da mentalidade dualista presente na época: "Apartar-se continuamente de tudo o que é corpóreo é viver sempre abrasado em amor, o que é próprio dos espíritos angélicos, não dos que vivemos neste corpo mortal". ${ }^{8}$ É necessária a contemplação da humanidade de Cristo para chegar aos últimos graus da vida mística. O contributo de Santa Teresa é propor um caminho que se distancia do dualismo. A humanidade de Cristo é a concretude, a materialidade, os seus sofrimentos. A vida espiritual, portanto, por mais que hajam êxtases, oração de quietude, não se pode afastar do concreto da humanidade de Cristo e nem deixar de se empenhar pelo empenho da vontade.

Contemplar a humanidade de Cristo significa afirmar que a revelação de Deus na história como sentido humanizador. Segundo Moingt, não tem sentido conhecer o Deus em si (o Deus filosófico), mas o Deus que vem para nós. Tal pensamento justifica os título dos seus livros que sempre revelam o Deus que vem. ${ }^{9}$ Somente o Deus revelado na história como sentido do ser humano tem sentido para a mentalidade do mundo depois da Ilustração: "O problema é salvar não somente a possibilidade de Deus 'ser pensado' pelo homem de hoje, mas a de o homem pensar a si mesmo". ${ }^{10}$

Por isso, o pensamento teológico assumiu uma "antropologização" no século XX: não trata mais Deus e sua existência a partir do ponto de visto filosófico, deixa para trás as provas cosmológicas, teleológicas e ontológicas, passando para o campo da antropologia, da experiência. ${ }^{11}$ A raiz desta linha de pensamento está em Feuerbach, que eleva a teologia à antropologia, destacando a afirmação elementar do Cristianismo: "Deus é homem e o homem é Deus". Eleva-se agora o home a um ser supremo. O Deus impassível do platonismo, segundo Feuerbach, é uma projeção das aspirações humanas; "Somente a miséria do homem é o lugar do nascimento de Deus", como retomariam Nietzsche e Marx. ${ }^{12}$

\footnotetext{
${ }^{7} 6 \mathrm{M} 7,6$.

${ }^{8} 6 \mathrm{M} \mathrm{7,6.}$

${ }^{9}$ MOINGT, Joseph. Deus que vem ao homem. Do luto à revelação de Deus. Volume I. São Paulo: Edições Loyola, 2010b, p. 13.

${ }^{10}$ Ibid., p. 437.

${ }^{11}$ Ibid., pp. 118-119; 122.

${ }^{12}$ Ibid., pp. 160-161.
} 
A Igreja Católica, mesmo demorando em adentrar no mesmo terreno antropológico que já havia sido trilhado pelo protestantismo, realiza a sua reconciliação com a modernidade no Concílio Vaticano II. Assim expressa o documento Gaudium et Spes: "Cristo manifesta plenamente o homem ao próprio homem e lhe descobre a sua altíssima vocação". ${ }^{13}$ Decorre do enunciado do documento conciliar que a antropologia teológica é uma antropologia cristológica, ou seja: Cristo é a chave de leitura para se compreender o ser humano, pois nele temos a plenitude humana. O extraordinário discurso de Paulo VI propõe o cristianismo como religião do humano que se revela em Jesus:

A religião católica é a vida da humanidade, porque descreve a natureza e o destino do homem, e dá-lhe o seu verdadeiro sentido. É a vida da humanidade, finalmente, porque constitui a lei suprema da vida, e à vida infunde a misteriosa energia que faz dela uma vida verdadeiramente divina. E se recordamos, veneráveis Irmãos e amados Filhos, todos vós que estais aqui presentes, como no rosto de todo o homem, sobretudo se se tornou transparente pelas lágrimas ou pelas dores, devemos descobrir o rosto de Cristo, o Filho do Homem; e se no rosto de Cristo devemos descobrir o rosto do Pai celestial, segundo aquela palavra: 'quem me vê a mim, vê também o Pai', o nosso humanismo muda-se em cristianismo, e o nosso cristianismo faz-se teocêntrico, de tal modo que podemos afirmar: para conhecer a Deus, é necessário conhecer o homem. ${ }^{14}$

O Deus para nós, Aquele que revela o sentido do ser humano, é manifestado em Cristo, em sua quenosis. Deus não proclama oráculos, não revela verdades obscuras, mas faz história. ${ }^{15}$ Assim, o cristianismo não é a manifestação do triunfo de Deus, mas de sua fraqueza na morte de Jesus. O grande escândalo da Igreja dos primeiros séculos continua sendo o escândalo hodierno: a afirmação de Deus que se encarnou radicalmente. No mundo greco-romano, a ideia de um Cristo de origem divina era facilmente aceita, pois era comum a concepção de uma pluralidade de seres divinos. $\mathrm{O}$ grande escândalo foi a afirmação de Deus que se encarnou radicalmente, que se

\footnotetext{
${ }^{13}$ Gaudium et Spes 22.

${ }^{14}$ PAULO VI. Discurso na última sessão do Concílio. Disponível em: <http://w2.vatican.va/ content/paul-vi/pt/speeches/1965/documents/hf_p-vi_spe_19651207_epilogo-concilio.html>. Acesso em 10 de abril de 2015.

${ }^{15}$ Moingt.. op. cit.. pp. 10-11
} 
exprimiu numa criança, que se humilhou para salvar o ser humano. Como afirma Paulo: "Ele se fez pobre para nos enriquecer de sua pobreza. Não se manifestou em poder dominador, como o todo-poderoso, mas como homem fraco, impotente, aquele que morreu. ${ }^{16}$ Hoje, estamos mais atentos para as fraquezas de Deus reveladas na Bíblia, pois elas fazem com que Deus seja mais próximo de nós: "mais humano, mais desarmado, menos poderoso do que nós acreditávamos". ${ }^{17}$

Deus não é um ídolo preso em seu templo, pronto para ser adorado. Ele entra na história dos seres humanos, comunicando a sua vida:

O nascimento de Jesus é, pois, evento de Deus que chega ao mundo, na medida em que é, segundo a 'disposição' trinitária deste evento, de uma parte, revelação e 'quenose' do Pai que se 'aniquila' em um homem, no filho que ele dá ao mundo ao assumir a 'condição' de sua existência temporal; de outra parte, revelação e 'envio' do Filho de Deus neste filho de homem que vem ao mundo recebendo 'a condição que o igualava a Deus', mas sem a 'reter orgulhosamente' para si, uma vez que se entregou ao mundo pelo ato do Pai que se entregava a ele (Fl 2,6-7).

Afirmamos inicialmente que o Deus revelado na quenosis de Jesus é relevante para o contexto pós-moderno. Moingt destaca alguns pontos que corroboram este argumento: ${ }^{18}$

- Jesus é um personagem singular. Jesus é um "personagem inclassificável", que não está confinado a nenhuma espera religiosa, ética, política e social, mas atravessa todas as esferas. Sua originalidade se revela como mensagem dissonante, que desestabiliza os ouvintes.

- A mensagem cristã é portadora de sentido, toca o profundo do ser, pois proclama o Deus histórico que faz brotar a vida da própria morte. O Cristianimo recusa um Deus estrangeiro à história e sem história, revelando um Deus presente na história e que tem ele próprio uma história. O Deus revelado em Jesus Cristo conduz à salvação ao passar pela história, revelando que a existência encontra sentido em curso natural. Um Deus que se declara a favor do ser humano em

\footnotetext{
${ }^{16}$ BOTTÉRO, Jean, et al. A mais bela história de Deus. Quem é o Deus da Bíblia? Volume 1. Rio de Janeiro: DIFEL, 2001, pp. 141-144.

${ }^{17}$ Ibid., p. 162.

${ }^{18}$ Moingt, 2008, pp. 49-59; 92.
} 
sua escolha de humanizar-se, não se recusando sua responsabilidade diante do mundo e de seus sofrimentos.

- O destino de Jesus revela o drama do indivíduo que enfrenta as leis sociais estabelecidas para viver a lei que descobriu estar inscrita no seu coração. O drama da fatalidade da morte vivido por Jesus revela que a morte é o caminho da liberdade.

- Jesus traz uma mensagem libertadora: acolhe o excluído, traz nova vida a quem se vê perdido e fora da sociedade, exorciza as mentes, liberta todos os que estão escravos de um passado, alivia as consciências tirando-as do medo, traz uma nova forma de vida baseada na fraternidade.

\section{Características de uma espiritualidade humanizadora}

Como vimos, o Deus revelado em Jesus Cristo, em sua humanidade quenótica, é reveladora do humano e fundamento para um discurso cristão significativo em nosso século. Diante destas premissas, com base em Moingt, apresentamos algumas características de uma espiritualidade humanizadora.

\subsection{Espiritualidade sem dualismos}

O dualismo, infiltrado de um modo equivocado no Cristianismo, causa sérias distorções na vivência de uma espiritualidade sadia. Marcião, no século II, considerava o mundo mau, por isso Deus não poderia ter assumido um corpo idêntico ao nosso. O dualismo de Marcião não foi a única voz da antiguidade e ainda continua presente nos tempos hodiernos. O Cristianismo preferiu optar pelo Deus da história, um Deus que está no mundo, o Deus já revelado no Antigo Testamento. Porém, esta escolha tem implicações que não foram levadas em conta. ${ }^{19}$

Para a superação do dualismo, é preciso resgatar o vínculo entre salvação e história: "Uma salvação que prometesse ao homem uma vida inteiramente nova, em que nada do que ele faz nem do que se torna na história fosse salvo, não seria moral, pois tiraria do homem a responsabilidade da história e não lhe permitiria assumir seu próprio destino de sujeito histórico". ${ }^{20}$ Não se trata

\footnotetext{
${ }^{19}$ Bottéro et al, op. cit., p. 165

${ }^{20}$ Moingt., op. cit., p. 273
} 
de enunciar um discurso, mas de construir uma história que se torna conteúdo de conversação com os seres humanos. A história trinitária opera a salvação no mundo: Deus vem para cuidar da paz, da unidade, da felicidade, depois faz desta ação conteúdo de sua revelação. A Trindade tem sentido para o ser humano na medida que se considera o "ser-com-Deus-para-o-mundo". ${ }^{21}$

Deus age no mundo, na história, na vida dos seres humanos. A encarnação do Verbo se prolonga na vida dos sujeitos históricos, de modo que o Espírito trabalha para que se construa a plenitude humana em Cristo, a associação de todos os redimidos no Corpo de Cristo:

Assim como o Verbo ainda em vias de se encarnar, indissoluvelmente associado ao Espírito, operava a salvação no passado da história pelo único fato de aí preparar sua encarnação, assim também o Espírito de Cristo opera a salvação no devir da história pelo simples fato de nela consumar a encarnação do Verbo, a saber, ao 'associar' aos destinados a seu corpo total 'aqueles que serão salvos' pela fé na mensagem salvífica de Jesus. Isso significa dizer que a encarnação se prolonga em toda carne, sob o modo, diferente, da habitação do Espírito, através da abertura permanente da linguagem humana à palavra de Cristo (palavra de Deus aos homens em e por Jesus): e é aqui que intervém a Igreja, a quem Jesus tinha confiado a palavra que o Pai lhe havia entregado. ${ }^{22}$

Diante dos dualismos tão presentes no contexto eclesial, é preciso resgatar a originalidade cristã: uma espiritualidade construída a partir da história, do humano, percebendo nestes âmbitos a ação divina, sem dicotomias. Não é necessária a fuga do mundo para encontrar a Deus, nem ver a história profana sempre em oposição à vontade divina. Uma espiritualidade dualista nega o humano e deve ser superada.

\subsection{Espiritualidade otimista: tirar o peso do pecado e da cruz}

Além do dualismo, a espiritualidade cristã sofre influência negativa de uma má compreensão sobre o pecado e a cruz de Jesus.

A centralidade do pecado não está em consonância com a prática de Jesus. Diferente de João Batista e de outros pregadores, Jesus não prega o castigo

\footnotetext{
${ }^{21}$ Idem, 2010a, p. 147.

${ }^{22}$ Moingt, 2012, p. 304.
} 
divino, mas o perdão. Sua missão é definida como missão de salvação e não como uma missão de julgamento (cf. Lc 5,31-32). As parábolas que falam do castigo e do juízo têm uma tônica escatológica. Sua intenção não é inspirar medo, mas sim exortar à vigilância. Haverá uma inversão: os presunçosos que se vangloriam de serem eleitos correm o risco de serem excluídos em detrimento dos que eram considerados os últimos de todos (cf. Lc 13,23-30). ${ }^{23}$

Algumas correntes ainda promovem um discurso centrado no pecado, associando-o à morte de Jesus na cruz, como se a cruz fosse um evento isolado e como se o sacrifício de Cristo fosse algo desejado por ele para sanar uma culpa ontológica, provocada pelo pecado de Adão e Eva. O pensamento da grande parte dos Padres da Igreja aponta para uma interpretação otimista da redenção. Para eles, a redenção seria a "restauração" da natureza humana em sua semelhança com Deus. Em outras palavras: se o ser humano foi criado à imagem e semelhança de Deus e se o pecado perverteu esta similitude, a encarnação do Verbo divino em Jesus Cristo teria como propósito restaurar o caráter de imagem e semelhança obscurecido pela força do pecado. Obviamente, os Padres da Igreja não deixaram de atribuir sentido redentor à paixão e à morte de Cristo. Eles entendiam estes acontecimentos como reparação e expiação. Contudo, o otimismo voltava a se manifestar, uma vez que prevalecia a ideia de que a bondade do Criador vem em socorro de Sua obra decaída, por causa de Sua justiça e castigo.

Após o surgimento, em Agostinho, da noção de pecado original, que marcou indelevelmente a humanidade com o peso da desgraça e da condenação, a cruz aparecerá de modo verdadeiramente trágico, já que ela seria signo da cólera divina. Assim, a redenção será pensada à parte da encarnação. A cruz será o lugar privilegiado para se pensar a redenção e a encarnação, consequentemente, aparecerá tão-somente como condição necessária para que a redenção na cruz fosse possível. A cruz aparece, então, como fonte de perdão e purificação dos pecados. Ora, o raciocínio que estrutura tal compreensão pode ser formulado do seguinte modo: Se os homens tinham incorrido na pena de morte, era preciso que o Filho de Deus realizasse uma substituição, sofrendo a pena em seu lugar. A cruz aqui se torna um sacrifício reparador, uma vez que ela é o lugar de substituição: Jesus substitui a humanidade pecadora. Ora, este pensamento acerca do sacrifício vicário de Jesus não engendra libertação, mas aumenta o peso sobre as costas dos seres humanos, já que,

${ }^{23}$ Idem, 2008, p. 270. 
se o Pai necessitou da morte do Filho para pagar uma dívida incomensurável contraída pela humanidade desde Adão, então, isto assinala a incapacidade de os seres humanos reconectarem-se com o Pai e experimentarem Seu amor incondicional. ${ }^{24}$

A visão otimista da redenção não se limita à expiação do pecado:

O papel de Cristo no plano de Deus é nos adquirir a 'redenção por seu sangue', que certamente inclui a 'remissão de nossas faltas' sem contudo limitar-se a uma obra de perdão e de expiação, sendo entendido que a salvação é um dom generoso e gracioso de Deus e que consiste fundamentalmente em que Deus nos escolheu em Cristo sem pôr condição nenhuma; realiza nosso 'resgate' no modelo da generosidade do Pai, pela troca de seu estatuto filial contra nossa destinação natural à morte..$^{25}$

Moingt assume a linha de Santo Irineu de Lião que proclama a salvação quando o ser humano é pleno, vivo. Defende a perspectiva soteriológica designada como "fisicista": entende que a natureza humana se transforma em sua união com Deus. Assim, todo homem verifica a sua perfeita "humanização" na encarnação do Filho, e sua divinização se cumpre no ato da encarnação do Verbo. O ser humano é regenerado pela participação sacramental "no Homem perfeito e total". ${ }^{26}$

Assim, Deus não olha para o ser humano de um modo neutro, não olha cada pessoa em si mesmo somente, mas o olha em Cristo. Quando nos vê, vê o seu projeto de ser que se realiza na ação de seu Verbo. Deus impele a criação para a sua plenitude, impele pela ação do seu Verbo que será unido à sua criação de modo pleno e pela ação do seu Espírito que age modelando o mundo para que atinja a sua plenitude..$^{27}$

O ser humano, nesta visão otimista, está dentro do projeto trinitário, que assim se resume: o Pai gera o seu Verbo na missão de unir-se ao criado e de exalar nele o seu Espírito a fim de reunir a criação no Reino definitivo. O projeto de Deus, portanto, não está em função do pecado, não se trata de um vir divino para resgatar o ser humano decaído, mas de criar o mundo em projeto de consumação em Cristo, já sonhado por Deus no ato da criação

\footnotetext{
${ }^{24}$ Idem, 2010a, p. 335.

${ }^{25}$ Ibid., p. 65.

${ }^{26}$ Moingt, 2008, p. 97.

${ }^{27}$ Idem, 2010a, p. 168.
} 
ou "antes" da criação do mundo, como afirma São Paulo: "somos levados a falar da criação pelo desvelamento que se faz em Cristo do 'projeto' de Deus em relação aos homens. Nele nos foi revelado que 'desde antes da fundação do mundo' Deus os elegeu para serem filhos adotivos por Cristo e para nele encontrarem 'a redenção e a remissão dos pecados' (Ef 1,4-7)". ${ }^{28}$

Assim, é preciso falar da criação do homem antes de falar da criação do mundo, e este em função do Cristo, modelo antropológico. O ser humano "é criado cocriador de sua humanidade" (nas palavras de Gesché), sendo criado numa "aventura espiritual”, engajado dentro de uma ação trinitária, uma ação contínua que o constrói ao longo da história. Não chegamos ainda ao final da singularidade dessa criação, pois o ser humano ainda precisa atingir a semelhança de seu criador, por um trabalho de liberdade que sintoniza e se engaja no projeto do amor de Deus. Segue-se um "projeto de adoção da humanidade por Deus", no qual a plenitude humana é revelada na ressurreição de Jesus e está "em projeto". Trata-se de um desígnio (Ef 1,11), de um sonho do amor divino. O texto do Gênesis não afirma que "Deus viu que era bom" ao sexto dia, mas viu que "era muito bom" (Gn1, 31). Não viu na criação o mal que seria introduzido pelo pecado, mas o bem do ser humano que ainda estava em projeto de ser. ${ }^{29}$

Uma espiritualidade humanizadora será fundamentada numa ideia positiva da criação, da salvação e da vida. Não será a tentativa de aplacar a ira de um deus-ídolo que parece arrumar pretextos para nos condenar, que nos vigia e está ávido pela reparação por intermédio do dolorismo e de práticas ascéticas. A espiritualidade será marcada pela alegria, pela busca da felicidade, fundada no Deus amor que deseja a nossa salvação. Mais do que a luta contra o pecado, a espiritualidade será o caminho do ser humano em busca de sua plenitude em Cristo, quando o sujeito se entende em processo de crescer em sua semelhança a Cristo, caminho para toda a existência, que terá a sua consumação para além da morte.

\subsection{Espiritualidade da relação}

Jesus proclamou o Reino, a Nova sociedade que traz em seu bojo duas características fundamentais: liberdade e amor fraterno. ${ }^{30}$

\footnotetext{
${ }^{28}$ Ibid., p. 162.

${ }^{29}$ Ibid., pp. 161-171.

${ }^{30}$ Moingt, op. cit., pp. 274-275.
} 
O amor a Deus e ao próximo são os principais mandamentos da lei. Sua novidade aparece na forma, não no conteúdo: afirma que o segundo é semelhante ao primeiro (Mt 22,39), porém o termo grego quer designar algo mais do que uma simples semelhança, significa igualdade de valor. Jesus relativiza o culto e proclama o amor de Deus como serviço ao próximo: "Não há maior amor do que dar a vida pelos seus amigos" (Jo 15,9.12-13). Não é suficiente o amor como a si mesmo, é preciso amá-lo mais do que a própria vida. ${ }^{31}$

Jesus proclama uma alteridade absoluta: o outro é igual a Deus. Não existe amor a Deus se não há amor ao próximo. Aqui tem uma implicação antropológica: Jesus não declara um "antropocentrismo totalitário" que vem em substituição de um "absolutismo teocêntrico", pois o eu não é absolutizado, e sim quem é diferente de mim. Para se projetar no "absoluto do Reino de Deus" é preciso tornar-se servo, sujeito do outro. ${ }^{32}$

A fé é intermediária da salvação (Mt 8,10-13). Mas a fé se une à caridade, não é somente crer no seu poder taumatúrgico, mas é sua compaixão que o leva a socorrer aqueles que estão oprimidos - a caridade é que opera a salvação. $\mathrm{Na}$ parábola do juízo final (Mt 25,31-46), deixa claro que o que for realizado ao menor dos irmãos, os mais pequeninos, é ao Senhor que foi realizado. É uma questão de fé, pois é preciso crer que no outro está o Senhor. Os atos religiosos não são exigidos, nada poderá remediar a ausência da caridade, ela sim está acima de qualquer prática. A fé e a caridade atingem o outro na alteridade: implica uma saída de si, um morrer para si mesmo, o que é mais importante de que todos os holocaustos e sacrifícios (Mc 12,33). A salvação não é mais encontrar um Salvador, reconhecê-lo, mas preocupar-se com as necessidades dos outros, reconhecer quem precisa, quem está com alguma carência: uma infelicidade carnal e temporal. ${ }^{33}$

Diante das referências cristológicas sobre o amor, a vida cristã se realiza no sair de si mesmo, na vida no Espírito:

A quem se contenta em viver o dia-a-dia, em reproduzir a existência do passado, em viver para si, a quem a existência no corpo nada mais é do que a vida 'na carne', segundo a expressão do Apóstolo, essas narrativas parecerão apenas o sonho inconsciente de uma vida melhor. Mas aquele que experimentou viver na frente e acima de si, inventar sua vida, perdê-la em

\footnotetext{
${ }^{31}$ Ibid., pp. 410- 412.

${ }^{32}$ Moingt, 2008, pp. 410- 415.

${ }^{33}$ Ibid., pp. 417- 429.
} 
proveito de outros, existência 'segundo o espírito', essa faz a experiência de ser ao mesmo tempo pela verdadeira vida e de ser incapaz de se apossar dela e fazê-la sua. Então, ele se dispõe a descobrir, na narrativa do que aconteceu a Jesus, a revelação dos Deus dos vivos, que só vive de dar a própria vida. (...) [A narrativa da ressurreição] só é revelação para os que entendem nela o chamado 'pascal' para partir, abandonar a si mesmo, 'desaparecer' construir a história pela qual Cristo voltará. ${ }^{34}$

Uma espiritualidade humanizadora será a humanização do sujeito a partir do empenho pela humanização do próximo. Uma espiritualidade que enxergue Deus no irmão, antes de vê-lo nas alturas ou nos ritos religiosos. A humanização é constrtuída a partir do amor, com todo o peso de conteúdo que carrega este termo na prática e ensinamento de Jesus.

\subsection{Espiritualidade da liberdade}

A ação divina na história, em especial a encarnação, é uma abertura para que o ser humano viva sua vocação à liberdade. Deus se limita em sua potência, porque respeita a nossa liberdade. Assim, recusa-se a intervir na história por "atos de poder" de um modo milagroso. Ele deseja que o ser humano livre aprenda a vender os limites da história, assumindo todos os aspectos de sua existência, eis a vocação humana. Por isso, Deus derrama o seu Espírito sobre "toda carne": faz com que nasçam filhos de Deus, pessoas chamadas à liberdade. Faz inclusive com que sua vontade fique entregue à história humana, às liberdades humanas, por isso o Filho de Deus está "entregue a nossas mãos". ${ }^{35}$ A humanização de Deus que limita a onipotência divina revela ao ser humano que ele precisa fazer a sua parte, mais do que depender de que tudo "caia pronto do céu".

Jesus é um homem livre. A força do Espírito o faz ter uma relação de liberdade com o Pai, fazendo o aderir à sua vontade. Na agonia do Getsêmani, compreendemos que Jesus não realiza a própria vontade (o seu Não), mas a vontade do Pai (o seu Sim). O Não de Jesus inverte-se no Sim eterno pronunciado pelo Pai: a ressurreição de Jesus, a recriação universal, a vida eterna. ${ }^{36}$

\footnotetext{
${ }^{34}$ Ibid., p. 333.

${ }^{35}$ Bottéro et al, 2001, p. 168.

${ }^{36}$ Moingt, 2010a, pp. 346-347.
} 
A prática de Jesus é um convite constante à liberdade, em especial no âmbito religioso: Jesus toma o lugar da lei e declara a libertação do jugo da religião: "Vinde a mim todos os que estão cansados sob o peso do vosso fardo..." (Mt 11,28-30). A salvação é a libertação trazida por Deus, não é um conjunto de leis e ritos que oprimem as pessoas incapazes de realizar tais práticas. Por isso, declara uma nova atitude: "Vinho novo, em odres novos" (Mc 2,22). Jesus ultrapassa o moralismo, exortando à procura da vontade de Deus, de um modo livre, não se preocupa com uma obediência prescrita. Ser assíduo às práticas religiosas não era ressaltado em suas pregações. Se os escribas se mantinham presos aos textos, para que o povo se mantivesse sob o seu jugo, Jesus tira o seu conhecimento de sua familiaridade com Deus. Sua proposta era de uma "religião interior" e não "estatutária" (expressão de Spinoza). Jesus ensina o povo a viver da fé, alimentando-se da Escritura e na alegre celebração em seu Templo, mas não se detinha nos textos, em definições formais, ritos... Tratava-se de uma fé pessoal que relativiza a mediação religiosa. Tal liberdade retira o medo do sagrado, aquele que impede se reconhecer o Deus amor. A obediência serviçal às formalidades religiosas mantém o crente como um escravo. Jesus rompe com esta religião, desejando que os discípulos se sintam livres, como filhos e filhas (Gl 4,1-4). ${ }^{37}$

A liberdade tem um valor crucial para o Cristianismo. Segundo Bonhöeffer, Deus prefere que o homem se torne livre, mesmo que o seu esforço para torná-lo livre o liberte das "tutelas da religião", prefere que seja livre de qualquer religião do que viver uma submissão infantil. ${ }^{38}$ Por isso, ninguém pode obrigar ninguém a nada, a nenhuma lei. A lei deve ser espontaneamente seguida, por amor, por liberdade. Ser obrigado a algo é contraditório: é viver sem liberdade, é tentar humanizar-se sem respeitar o que é radical na humanização: a liberdade da consciência. ${ }^{39}$

Cada um deve assumir diante de Deus a responsabilidade por seus julgamentos e por seus atos, deve decidir se um deve ético não o leva a superar um preceito religioso, deve suavizar sua obediência a Deus do peso insuportável que a tradição dos homens a ela acrescenta. Ele coloca o princípio da liberdade do acesso a Deus sem passar pelos constrangimentos das mediações religiosas. (...) Porque ele torna relativa a obediência à lei

\footnotetext{
${ }^{37}$ Moingt, 2008, pp. 398-404.

${ }^{38}$ Idem, 2012, p. 283.

${ }^{39}$ Idem, op. cit., pp. 453-460.
} 
religiosa, dá toda força à lei ética, abre o campo ético, completamente profano que é, como lugar onde Deus se dá a encontrar, incógnito, e onde a caridade fraterna assume a seus olhos valor de fé para com sua paternidade universal (Mt 25).40

A libertação que deve se efetivar não é apenas dos esquemas sociais e religiosos, deve começar a partir do próprio sujeito (libertação interior, de si mesmo). É preciso que o mesmo se liberte de seus desejos egoístas e apegos que condicionam e limitam a sua liberdade, suas escolhas. Precisa amar na gratuidade, até perder-se de si em proveito do outro, de ampliar sua capacidade relacional de modo a incluir todos os que estão colocados diante dele, de engajar-se para construir o mundo, para fazer o bem comum às gerações que estão por vir. ${ }^{41}$

Deus chama o ser humano a construir sua "liberdade em excesso", enfrentando os limites que se impõe por sua presença no mundo. Deve libertarse do pecado. Moingt entende que o pecado é a resistência contra o projeto de Deus, ser contra ao que está predestinado a ser, ir contra ao "trabalho de parto" da criação para que o mundo e o ser humano atinjam a sua plenitude. Ser para o mundo ao invés de ser-para-o-outro. ${ }^{42}$

A liberdade, nesta linha, é algo que se constrói ao longo da história pessoal de cada um, um projeto de liberdade:

A liberdade do homem é essencialmente temporal: não consiste simplesmente em fazer escolhas instantâneas, mas em tornar-se livre, mesmo em relação a suas escolhas futuras, a ficar senhor de si, e nunca é acabado; o homem nunca termina de ser livre enquanto vive, enquanto conserva possibilidade de voltar atrás em suas escolhas contrárias de seus antigos apegos; pode sempre preferir a imobilidade de ser-coisa. ${ }^{43}$

Uma espiritualidade humanizadora será progressiva construção da liberdade do cristão. O sujeito, pela ação do Espírito, pelo discernimento, deve se abrir para avançar na liberdade exterior e interior. Libertar-se de si mesmo, do seu egoísmo e dos esquemas que negam sua humanidade. $\mathrm{O}$ de humanização é um processo de libertação.

\footnotetext{
${ }^{40}$ Idem, 2010b, p. 314.

${ }^{41}$ Idem, 2010a, p. 166.

${ }^{42}$ Ibid., p. 175.

${ }^{43}$ Ibid., pp. 335-336.
} 


\section{Conclusão}

Uma espiritualidade significativa para o contexto pós moderno deve ser construído a partir de Cristo como revelador humano, que se dá em sua história quenótica. Assim, chegamos a traçar algumas linhas para uma espiritualidade humanizadora. Outras tantas características poderiam ser assinaladas. Escolhemos algumas, a partir dos textos do teólogo Joseph Moingt. As duas primeiras são, na verdade, resgates de um sentido e originalidade perdidos: a superação do dualismo e a visão otimista da criação e salvação. As duas últimas tocam a essência da humanização na relação do sujeito consigo mesmo, com o próximo e com o mundo: a superação do egoísmo realizado a partir de um olhar especial para o próximo, imagem de Deus e o trabalho de construção da própria liberdade. Todo este caminho de construção humana que aqui chamamos de espiritualidade é um caminho progressivo que não se realiza pela mera ascese do indivíduo, mas pela abertura à ação da graça.

\section{Referências bibliográficas}

BINGEMER, Maria Clara Lucchetti. O Mistério e o Mundo. Paixão por Deus em tempos de descrença. Rio de Janeiro: Rocco, 2013.

BOFF, Clodovis. O livro do sentido. Crise e busca do sentido hoje (parte crítico-analítica). Volume 1. São Paulo: Paulus, 2014.

BOTTÉRO, Jean; QUAKNIN, Marc-Alain; MOINGT, Joseph. A mais bela história de Deus. Quem é o Deus da Bíblia? Volume 1. Rio de Janeiro: DIFEL, 2001.

KASPER, Walter. Igreja Católica: essência, realidade e missão. São Leopoldo: Unisinos, 2012.

MOINGT, Joseph. O homem que vinha de Deus. São Paulo: Edições Loyola, 2008.

MOINGT, Joseph. Deus que vem ao homem. Da aparição ao nascimento de Deus. Volume II - Aparição. São Paulo: Edições Loyola, 2010a.

MOINGT, Joseph. Deus que vem ao homem. Do luto à revelação de Deus. Volume I. São Paulo: Edições Loyola, 2010b. 
MOINGT, Joseph. Deus que vem ao homem. Da aparição ao nascimento de Deus. Volume II - Nascimento. São Paulo: Edições Loyola, 2012.

MOLTANN, J. O Espírito da Vida: uma pneumatologia integral. Petrópolis: Vozes, 2010.

PAULO VI. “Discurso na última sessão do Concílio". Disponível em:

$<$ http://w2.vatican.va/content/paul-vi/pt/speeches/1965/documents/hf_p-vi_ spe_19651207_epilogo-concilio.html>, Acesso em 10 de abril de 2015.

SANTA TERESA DE JESUS. Castelo interior ou Moradas. São Paulo: Paulus, 1997.

Roberto Nentwig

Mestrado em Teologia Sistemático Pastoral pela PUC-PR Doutorando em Teologia do programa de Pós-Graduação da PUC-RIO

Rio de Janeiro / RJ - Brasil

E-mail: beto.catequese@gmai.com

Recebido em: 21/05/15

Aprovado em: 25/06/15 